\title{
Twist Open/Close Dispensing Plastic Container Closure
}

National Cancer Institute

\section{Source}

National Cancer Institute. Twist Open/Close Dispensing Plastic Container Closure. NCI

Thesaurus. Code C96137.

Two-piece dispensing closure that has a lower portion designed to attach and seal securely to a container finish and the upper portion of which is designed to receive a dispensing spout member. Rotating the spout member opens and closed the container. 